\title{
Evaluation of Nutritional and Anti Nutrition Factors of Orange-fleshed Sweet Potato and Haricot Bean Blended Mashed Food for Pre-school Children: The Case of Dale Woreda, Southern Ethiopia
}

\author{
Abebe Haile ${ }^{1, *}$, Dereje Getahun ${ }^{2}$ \\ ${ }^{1}$ Centre for Food Security Studies, College of Development Studies, Addis Ababa University, Ethiopia \\ ${ }^{2}$ School of Nutrition, Food Science and Technology, College of Agriculture, Hawassa University, Ethiopia
}

Copyright $\mathrm{O} 2018$ by authors, all rights reserved. Authors agree that this article remains permanently open access under the terms of the Creative Commons Attribution License 4.0 International License

\begin{abstract}
Protein-energy malnutrition and vitamin A deficiencies are among the public health problems in Ethiopia. The objective of the study was to assess the nutritional composition of Orange-Fleshed Sweet Potato and haricot bean $(70: 30,80: 20,90: 10$ and 100:0.0) formulated mashed food. The collected data were analyzed using SPSS version 16.0 and SAS version 9.0 Software. Completely randomized design was used to compare the effect of different proportion on proximate composition, minerals, anti-nutrients, bio-availability and $\beta$-carotene contents. Standard methods were used to evaluate the proximate composition, anti-nutritional factors, mineral contents $(\mathrm{Ca}, \mathrm{Zn}$ and $\mathrm{Fe})$ and there bio-availability, and $ß$-carotene of formulated mashed foods. The survey results showed that preschool children were not consuming protein and vitamin A rich foods frequently to meet their Recommended Dietary Allowance (RDA) of protein and vitamin $\mathrm{A}$. The proximate composition indicated as the proportion of haricot bean increased the moisture and carbohydrate contents were decreased. On the contrary $\mathrm{Ca}$, $\mathrm{Fe}, \mathrm{Zn}$, phytate and tannin were increased as the proportion of haricot bean increased. All phytate to minerals molar ratios were observed below the critical limits. The nutritionally improved and acceptable mashed foods can be prepared from OFSP and haricot bean at 70:30 proportions. Nutrition education using food-based interventions were also recommended in the study area to improve nutritional status of preschool children.
\end{abstract}

Keywords Haricot Bean, Bio-availability, ß-carotene, Mashed Food, Anti-nutritional Factors

\section{Introduction}

During the time that scientists have been studying nutrition, no nutrient has been more intensely scrutinized than protein. Protein is among the indispensable nutrient to life. It should come as no surprise that protein deficiency can have devastating effect on people's health. When people are deprived of food and suffer an energy deficit, they degrade their own body protein for energy and indirectly suffer a protein deficiency, as well as an energy deficiency. Because protein and energy deprivation go hand in hand, public health officials have adopted an abbreviation for the overlapping pair: protein-energy malnutrition (PEM). Protein-energy malnutrition takes two different forms, with some cases exhibiting a combination of the two. In one form, the person is shriveled and emaciated - this condition is called Marasmus. In the second, a swollen belly and skin rash are present, and the condition is named kwashiorkor. In the combination, some features of each type are present. Marasmus reflects a chronic inadequate food intake and therefore inadequate energy, vitamins and minerals, as well as too little protein. Kwashiorkor may result from severe malnutrition, with too little protein to support body function [1].

Pulses in general, and haricot bean in Africa have constituted an important food category for humans. For thousands of year's food from pulses were incorporated in various forms into most traditional diets around the globe. Beans are a very important food crops in many parts of Eastern and Southern Africa [2]. Together with maize and cassava, they have been dominant staple in the Americans for centuries. As a food group, pulses have several interesting attributes including their high nutritional value. Pulses can serve as valuable source of energy. The energy content of cooked pulses value has been found in the range from $300-540 \mathrm{Kcal} / 100 \mathrm{~g}$ [3]. The energy of pulses comes from the nutrient supply of mainly protein and carbohydrate. Pulses have high protein content and thus, can help to improve the protein content of meals $[3,4]$. The 
protein content of most pulses is between 20 and $30 \mathrm{~g}$ per $100 \mathrm{~g}$, twice as much protein as grains and almost similar in protein content to meat [5].

Pulse supplementation to one Ethiopian traditional food increased total protein concentrations on a dry-weight basis Incorporating kidney bean to maize comes up with $58 \%$ increment of its protein content [6]. Beans are deficient in sulphur-containing amino acids such as methionine and cysteine, but they are rich in lysine. When combined with grains, pulses provide almost all of the essential amino acids required for human growth and development. Pulses are also suitable for people requiring a gluten-free diet. Pulses are low in fat, containing $2-6 \%$ fat, most of which is provided by polyunsaturated fatty acids. Being plant foods, grains contain no cholesterol, but they do contain sterols. Plant sterols are known for their cholesterol-lowering effect [4]. Pulses were slowly digested carbohydrate or low glycemic index. In addition, pulses are rich in insoluble and soluble fibers, resistant starch and oligosaccharides [3].

Among pulses haricot bean contains the highest amount of carbohydrates and calcium. Lentil is highest in iron and zinc. Orange-Fleshed Sweet Potato (OFSP) is a nutritious food, rich in carbohydrate and a good source of energy $(293-460 \mathrm{KJ} / 100 \mathrm{~g})$ but low in fat, cholesterol and protein [7]. The protein content is generally low, ranging from 1 to $8.5 \%$ [7, 8]. Tubers and leaves are good sources of antioxidants, fiber, zinc, potassium, sodium, manganese, calcium, magnesium, iron and vitamin c [8,9]. Because of their nutritional qualities, sweet potatoes were selected as one of the foods tested for long-term space travel [10]. Sweet potato can contain as much as $44 \%$ dry matter; however, most commercial cultivars contain $20-30 \%$ dry matter [11]. The major components of dry matter are carbohydrates which make up $90 \%$ of dry matter in most cultivars $[11,12]$. All varieties of sweet potato are good sources of vitamin $\mathrm{C}$ and $\mathrm{E}$ as well as dietary fiber. The orange and red-fleshed forms of sweet potato are particularly high in $\beta$-carotene [11]. The fiber content in sweet potato varies to a great extent depending on vertical variation and age of the crop, where the fiber content increases with the maturity. Fiber content in flour derived from tuber extractions may vary to greater extent on the techniques and sieves used for removal of the fibrous material [13].

Substituting sweet potato for other ingredients dramatically increased the $\beta$-carotene content of processed food products. Well stored sweet potatoes have retained most of their carotenoids for at least 50 days or longer [8]. Thus, the effects of boiling and storage method are causing losses of about $20 \%$ while drying into chips reduced the amount of total carotenoids from $16-30 \%$ compared to the amount in fresh roots. Even though there is loss, the amount of total carotenoids was high, indicating that the OFSP has an important nutritional value [14].Traditional Indian foods such as mandazi, chapattis, and buns made from wheat flour contained approximately $18-20 \mu \mathrm{g} R$ per $100 \mathrm{~g}$ of food product, whereas the products containing OFSP ranged from $91-259 \mu \mathrm{g}$ RE per $100 \mathrm{~g}$, a value 4.5 to 14 times greater.

The consumption as little as $50 \mathrm{~g}$ of OFSP in a day may provide a child's Recommended Dietary Allowance (RDA). Nutritionists have determined that the regular consumption of relatively modest amounts of boiled OFSP by young school children in South Africa significantly improved their vitamin A (VA) status. Therefore, even if OFSP is not a preferred diet for an individual consumer, one needs to add only a small portion on top of her/his choice $[15,7]$. Sweet potato has a comparative advantage over other common staple foods especially cereals and legumes which provide zero to minor traces of $\beta$-carotene equivalents and farmers with small plots can adapt it as back garden crop for daily household dietary supplementations [16].

An efficacy trial that was conducted in South Africa showed that also feeding $125 \mathrm{~g}$ OFSP to school children for 5 days a week for 3 months significantly improved amounts of vitamin A stored in the liver [15, 17]. Effectiveness of the OFSP to improve VA status was also shown in Mozambique. The introduction of OFSP in an integrated agriculture and nutrition intervention resulted in improved dietary VA intake and serum retinol concentrations in young children [7]. An impact case study conducted by CIP and Michigan State University suggested that replacing the current white-fleshed varieties with new orange-fleshed varieties that are high in $\beta$-carotene content would benefit an estimated 50 million children under the age of six in Africa who are currently at risk of Vitamin A Deficiency (VAD) [7]. Although many sweet potato growing countries traditionally eat cream or white sweet potatoes, studies that have asked them to switch from white to orange potatoes have found little resistance. Thus, the impact of consumer preference on the success of OFSP program to prevent VAD is small $[8,7]$. According to the report of Vitamin A for Africa (VITAA) in countries such as Rwanda, Burundi, and Uganda, where sweet potato production was high, full adoption of OFSP could resolve VAD completely for 85 to $95 \%$ of children most at risk in addition to significant benefits for women of childbearing age. Even in countries that were not major sweet potato producers, such as Ethiopia, a third of the population would enjoy partial benefits from enhanced $\beta$-carotene intake as a result of switching from white to orange fleshed varieties. In Ethiopia 8.89 million children (6 month to 6 years old) are at risk of VAD, only $1.8 \%$ of the population have fully benefited from OFSP $[18,7]$. The average Ethiopian annual increase in pro-VA intake (RDA) is $2.3 \%$.Other Sub-Saharan African countries such as Rwanda and Burundi have benefited more than $90 \%$ from OFSP [7]. Eleven countries in Sub-Saharan Africa are members of CIP's successful-VITAA platform that is promoting the breeding, consumption and sale of locally 
adapted conventionally bred $\beta$-carotene rich OFSP varieties.

Among roots and tuber plants product in Ethiopia white fleshed varieties were one of the dominantly grown crops in the country. Particularly, in the Southern regional state 13 million people consume white fleshed sweet potato as staple food. To alleviate VAD through diet diversity, Ethiopia at Awassa Agricultural Research Center in collaboration with CIP launched breeding program for VA rich OFSP. In fact before targeting to breed for vitamin A rich sweet potato against VAD, Ethiopia agriculture research released two yellow/OFSP varieties from local collections in the year 1987 and 1997 for root yield i.e. Koka - 12 and AJAC - 1 with total root yield 25.4 and 35.35 $\mathrm{t} / \mathrm{ha}$, respectively. However, these varieties were not well adopted due to their texture (moist) and color. Activities to popularize OFSP varieties have also been undertaken through bazaar, workshop, public media and other extension means and have resulted in high demand for more OFSP cuttings [19].

Vitamin A Deficiency is a public health problem worldwide. An estimated 250 million pre-school children may be deficient of vitamin A according to WHO report. Vitamin A deficiency is common especially in South-east Asia and Sub-Saharan Africa, where $40 \%$ of pre-school children are estimated to be deficient. It is a leading cause of preventable blindness in the world [8]. Between 250,000 and 500,000 children go blind every year and over 600,000 deaths of children annually may be attributed to VAD $[8$, 20]. Over $4-6 \%$ of all disease burden in Africa is estimated to result from VAD [21, 22]. High malnutrition rates in Ethiopia pose a significant burden in economic and social development [23].The most common forms of malnutrition in Ethiopia are PEM, VAD, Iodine deficiency disorders, and Iron deficiency anemia [24, 25]. Food-based strategies were keys to address hunger and malnutrition, and the desired characteristics of foods include high nutrient density as well as utilization of low cost and locally-available crops. This will ensure early adoption at home and at the village level [26]. Improving the nutritional status of infants, young children and children under five is one of the strategic objectives of national nutrition program of Ethiopia (FDRE NNP, 2013 - 2015). To attain this objective, one of the tools is food based interventions. Food based interventions include producing and consuming varieties of foods. The interventions have to be suitable for the local set-up that considers the purchasing power and locally available resources of the community. Pulses are cheaper sources of protein, especially for low-income households' pre-school children for physical as well as mental development. This study, therefore, came up with a food based intervention which was suitable for the rural community. People living at Dale woreda can formulate nutritionally improved mashed food from OFSP and haricot bean and feed their children to alleviate PEM and VAD. Thus the formulated food helps to improve the nutritional status of pre-school children at the studied area. The study focused: to formulate mashed foods from OFSP and haricot bean in different proportions and analyzed nutritional composition of the formulated food.

\section{Materials and Methods}

\subsection{Collection and Preparation of OFSP and Haricot Bean}

Orange-fleshed sweet potato (OFSP) (Ipomea batatus) was prepared by [7] method with slight modification. Orange fleshed sweet potato, Tulla variety, was bought from two members of the study populations (one from each kebeles). Then it was washed with clean water until all the soil was removed. Tips, roots and other inedible portions were discarded. Then the OFSP was placed in a clean black plastic bag and tighten. This was to retain $\beta$-carotene during cooking. Then it was placed in a clean saucepan which contained enough water and then cooked until the OFSP became soft.

Haricot bean (Phaseolus vulgaris) was prepared by [27] method with slight modification. Haricot bean (red, small) was bought from local market of the study area. Then it was cleaned by hand to remove extraneous objects. Then it was washed with clean water until it was free from any dirt. Then after, it was placed in a clean saucepan which contained clean water in 1:5 w/v ratios. Then it was cooked until it became soft enough to mash. When it was soft, it was allowed to stay on gentle heat to absorb the residual water. And to retain minerals which were leached during cooking.

\subsection{Formulation of OFSP-Haricot Bean Mashed Foods}

When the OFSP was simmered to the desired level, it was transferred to a clean bowl while it was tighten with the plastic. The plastic was loosened and the OFSP together with the residue water in the plastic were discharged to the bowl. When cooled, it was manually peeled and mashed in the bowl together with the residue water. When the haricot bean was cooked to the desired level and the residue water was drained to (absorbed by) the haricot bean, it was transferred from the saucepan to a clean bowl. Then it was mashed with clean glass bottle. To avoid any food reduction, the haricot bean was not dehulled. This was because the community usually do not dehull haricot bean. The community does so by thinking the quantity of the meal reduces if it is dehulled. After mashing respectively the OFSP and haricot bean separately, four types of foods were formulated based on Eastern and Central Africa Sweet Potato Recipe Book Guideline [28]. The foods were formulated in the following ratios (OFSP: haricot bean): 100:0, 90:10, 80:20 and 70:30 by adding iodized salt $1 \mathrm{~g}$ per $100 \mathrm{~g}$ food. 


\subsection{Determination of Proximate Composition of Formulated Mashed Foods}

In order to determine their moisture content, crude protein, crude fat, crude fiber and total ash, samples of formulated mashed foods were chemically analyzed according to AOAC method [29]. Total carbohydrate content was determined by difference. It was determined by subtracting the moisture content, crude protein, total ash and crude fat from the total dry weight of the sample.

\section{Total carbohydrate $(\%)=100-($ fat $\%+$ protein $\%+$} moisture $\%+$ ash \%)

Gross energy was determined by calculation from crude (protein, fat), and carbohydrate contents using the Atwater's conversion factors;

$$
\begin{gathered}
\text { Gross energy }(\text { Kcal } / 100 \mathrm{~g})=(4 \times \text { protein })+(4 x \\
\text { carbohydrate })+(9 x \text { fat })
\end{gathered}
$$

\subsection{B-carotene Content Analysis}

The $\beta$-carotene was determined by open column chromatography spectrometer method as described by [30]. About $2.00 \mathrm{~g}$ of sample was weighed, mixed and extracted with mortar and pestle in the presence of acetone. Then, the extracted sample was filtered into $100 \mathrm{~mL}$ volumetric flask in addition the mortar, funnel and residue were washed with small amount of acetone and filtered in flask containing the extract. Again the residue was returned to the mortar, fresh acetone was added macerated, washed and filtered as before. The extraction and filtration were repeated until the residue devoid of any color and the washing were colorless. Then, petroleum ether of $25 \mathrm{~mL}$ and acetone extract were poured in a separate funnel and shacked well, in addition small amount of distilled water was added to separate the two phase and the lower aqueous-acetone phase was discarded. Again the separator funnel was washed 2-3 times with water and residue acetone was removed. Then, the petroleum ether phase was collected, dried with sodium sulphate until some crystal become loose, transferred to drying flask and evaporated to a rotary evaporator. Then, the residue was dissolved in about $1 \mathrm{~mL}$ of petroleum ether and solution was introduced in to the chromatographic column. The column was eluted with petroleum ether and the $\beta$-carotene was collected in a flask and went through a column as a yellow pigment. Finally the volume of $\beta$-carotene was measured using measuring cylinder and the absorbance was read at $440 \mathrm{~nm}$ spectrometer. The amount of $\beta$-carotene was calculated by using the following equation:

$$
\text { B-carotene }(\mu \mathrm{g} / \mathrm{g})=[\mathrm{A} \times \mathrm{V}(\mathrm{ml}) \times 104] /\left[A_{1 \% 1 \mathrm{~cm}} \times \mathrm{W}\right]
$$

Where:

$\mathrm{A}=$ Absorbance, $\mathrm{A}_{1 \% 1 \mathrm{~cm}}=$ Absorption coefficient of carotenoid in solvent used petroleum is 2592,

$\mathrm{V}(\mathrm{mL})=$ Volume of the solution that gives an absorbance of $\mathrm{A}$ at a specified wavelength and

$$
\mathrm{W}=\text { Weight }(\mathrm{g}) \text { of the sample }
$$

\subsection{Minerals Content Analysis}

About $1.5 \mathrm{~g}$ of sample was put in the oven at $100^{\circ} \mathrm{C}$ for $30 \mathrm{~min}$. when dry, heat on hot plate until smoke finished and then the dish was placed in $525^{\circ} \mathrm{C}$ furnace for minimum time necessary to obtain ash that is white and free from carbon normally $3-5 \mathrm{hs}$ but $\leq 8 \mathrm{hs}$. The dish was removed from furnace and cooled. The ash should be white and free from carbon. The ash was dissolved in $5 \mathrm{ml} 1 \mathrm{M}$ $\mathrm{HNO}_{3}$ warming on steam bath or hot plate 2-3 min to aid in solution. The solution was added in to $50 \mathrm{~mL}$ volumetric flask and repeat with 2 additional portion of $1 \mathrm{M} \mathrm{HNO}_{3}$. The minerals was determined by adding $\mathrm{LaCl}_{3}$ (Lanthanum chloride) solution to final dilution of standard and test solution to make $0.1 \%(\mathrm{w} / \mathrm{v})$ La for determination of the minerals. Iron, zinc and calcium contents of the samples were determined according to AOAC method [29]. After removal of organic material by dry ashing, the residue was dissolved in diluted acid. The solution was sprayed into the flame of Atomic Absorption Spectrophotometer (Varian Spectra AA-20 Plus, Australia) and the absorption of the minerals was measured at a specific wavelength.

Standard solutions: The stock standard solutions of the minerals (iron, zinc and calcium) were diluted with $0.3 \mathrm{~N}$ $\mathrm{HCl}$ to concentrations that fall within the working range. The Atomic Absorption Spectrophotometer (AAS) was calibrated using standard solutions and the reagent blank solution was run with the sample. The mineral content was calculated by using the following equation:

$$
\text { Mineral content }(\mathrm{mg} / 100 \mathrm{~g})=[(\mathrm{a}-\mathrm{b}) \times \mathrm{V}] / 10 \mathrm{~W}
$$

Where:

$\mathrm{W}=$ Weight (g) of sample; $\mathrm{V}=$ Volume $(\mathrm{V})$ of extract; a

$=$ Concentration $(\mu \mathrm{g} / \mathrm{mL})$ of sample solution;

$\mathrm{b}=$ Concentration $(\mu \mathrm{g} / \mathrm{mL})$ of blank solution.

\section{Anti-nutritional Factors Content Analysis}

\subsection{Determination of Phytate Content}

Phytate was determined by the method of [31]. About $0.1 \mathrm{~g}$ of dried sample was extracted with $10 \mathrm{~mL} 2.4 \% \mathrm{HCl}$ in a mechanical shaker for $1 \mathrm{hr}$ at an ambient temperature and centrifuged at $3000 \mathrm{rpm}$ for 30 minutes. The clear supernatant was used for phytate estimation. A $2 \mathrm{~mL}$ of wade reagent (containing $0.03 \%$ solution of $\mathrm{FeCl}_{3} \cdot 6 \mathrm{H}_{2} \mathrm{O}$ and $0.3 \%$ of sulfosalicilic acid in water) were added to 3 $\mathrm{mL}$ of the sample solution (supernatant) and the mixture was mixed on a Vortex for 5 seconds. The absorbance of the sample solutions was measured at $500 \mathrm{~nm}$ using UV-VIS spectrophotometer (Beckman DU-64, USA). A series of standard solutions were prepared containing 0,5 , 10,20 and $40 \mu \mathrm{g} / \mathrm{ml}$ of phytic acid (analytical grade sodium 
phytate) in $0.2 \mathrm{~N} \mathrm{HCl}$. A $3 \mathrm{~mL}$ of standard was added into $15 \mathrm{~mL}$ of centrifuge tubes with $3 \mathrm{~mL}$ of water which was used as a blank. A $1 \mathrm{~mL}$ of the Wade reagent was added to each test tube and the solution was mixed on a Vortex mixer for 5 seconds. The mixture was centrifuged for 10 minutes and the absorbance of the solution (both the sample and standard) was measured at $500 \mathrm{~nm}$ by using deionized water as a blank. A standard curve was made from absorbance versus concentration and the slope and intercept was used for calculation.

Phytic acid $(m g / 100 \mathrm{~g})=($ absorbance - intercept $) /($ slope $x$

$$
\text { oxwt. of sample } x \text { 10) }
$$

Where; $\rho$ - density, wt - weight

\subsection{Condensed Tannin Content}

Tannin content was determined by the method of [32]. About $2 \mathrm{~g}$ of dried sample was weighed in a screw cap test tube. The sample was extracted with $10 \mathrm{~mL}$ of $1 \% \mathrm{HCl}$ in methanol for 24 hours at room temperature with mechanical shaking. After 24 hours shaking, the solution was centrifuged at $1000 \mathrm{rpm}$ for 5 minutes. A $1 \mathrm{~mL}$ of supernatant was taken and mixed with $5 \mathrm{~mL}$ of vanillin- $\mathrm{HCl}$ reagent (prepared by combining equal volume of $8 \%$ concentrated $\mathrm{HCl}$ in methanol and $4 \%$ vanillin in methanol). D-catechin was used as standard for condensed tannin determination. A $40 \mathrm{mg}$ of D-catechin was weighed and dissolved in $1000 \mathrm{~mL}$ of $1 \% \mathrm{HCl}$ in methanol, which was used as stock solution. A 0.0, 0.2, 0.4, 0.6, 0.8 and 1 $\mathrm{mL}$ of stock solution was taken in test tube and the volume of each test tube was adjusted to $1 \mathrm{~mL}$ with $1 \% \mathrm{HCl}$ in methanol. A $5 \mathrm{~mL}$ of vanillin- $\mathrm{HCl}$ reagent was added into each test tube. After 20 minutes, the absorbance of sample solutions and the standard solution were measured at 500 $\mathrm{nm}$ by using water to zero the spectrophotometer, and the calibration curve was constructed from the series of standard solution using SPSS-15. A standard curve was made from absorbance versus concentration and the slope and intercept were used for calculation. Concentration of tannin was read in $\mathrm{mg}$ of D-catechin per $100 \mathrm{~g}$ of sample:

Tannin $(\mathrm{mg} / \mathrm{l} 100 \mathrm{~g})=($ absorbance - intercept $) /($ slope $x$ density $x$ weight of the sample $x$ 10)

\subsection{Determination of Molar Ratio of Phytate/Mineral (Bioavailability)}

The mole of phytate and minerals was determined by dividing the weight of phytate and minerals with its atomic weight (phytate: $660 \mathrm{~g} / \mathrm{mol}$; Fe: $56 \mathrm{~g} / \mathrm{mol} ; \mathrm{Zn}: 65 \mathrm{~g} / \mathrm{mol}$; Ca: $40 \mathrm{~g} / \mathrm{mol}$ ). The molar ratio between phytate and mineral was obtained after dividing the mole of phytate with the mole of minerals. The critical molar ratio, above which ion absorption may be impaired is PA: $\mathrm{Ca}>1.56$, PA:Fe $>14$ and PA:Zn $>10$ [33].Depending on the values from the molar ratios, the bioavailability of the minerals was judged.

\section{Data Analysis}

The data analyses were subjected to one way analysis of variance (ANOVA) by using SAS version 9.0 Software. The mean separation values were determined using Fischer LSD test. Significant differences were declared at $p<0.05$.

\section{Results and Discussion}

\section{Nutrient Compositions of Mashed OFSP and Haricot Bean}

The results of nutritional composition and anti-nutrients contents of mashed OFSP and haricot bean are shown in table 1 .

Table 1. Proximate composition, gross energy, minerals', anti-nutritional factors' and vitamin A contents of mashed OFSP and haricot bean

\begin{tabular}{|c|c|c|}
\hline Composition & mashed OFSP & mashed haricot bean \\
\hline Moisture (\%) & $72.12 \pm 0.67$ & $59.32 \pm 1.4$ \\
\hline Crude protein $(\%)$ & $4.59 \pm 0.19$ & $19.16 \pm 0.29$ \\
\hline Crude Fat $(\%)$ & $1.62 \pm 0.05$ & $3.65 \pm 0.23$ \\
\hline Crude ash (\%) & $1.39 \pm 0.18$ & $2.62 \pm 0.19$ \\
\hline Carbohydrate $(\%)$ & $20.29 \pm 0.62$ & $15.25 \pm 1.50$ \\
\hline Crude fiber $(\%)$ & $2.23 \pm 0.28$ & $4.73 \pm 0.13$ \\
\hline Energy $(\mathrm{Kcal})$ & $114.10 \pm 3.67$ & $170.56 \pm 5.06$ \\
\hline Calcium $(\mathrm{mg} / 100 \mathrm{~g})$ & $39.10 \pm 3.20$ & $58.93 \pm 3.62$ \\
\hline Zinc $(\mathrm{mg} / 100 \mathrm{~g})$ & $0.40 \pm 0.23$ & $3.50 \pm 0.62$ \\
\hline Iron $(\mathrm{mg} / 100 \mathrm{~g})$ & $0.74 \pm 0.12$ & $11.78 \pm 1.70$ \\
\hline Tannin $(\mathrm{mg} / 100 \mathrm{~g})$ & $56.14 \pm 3.14$ & $803.74 \pm 28.42$ \\
\hline Phytate $(\mathrm{mg} / 100 \mathrm{~g})$ & $40.00 \pm 3.28$ & $104.35 \pm 2.28$ \\
\hline Vitamin A $(\mu \mathrm{g} \mathrm{RE})$ & $799.93 \pm 42.43$ & $0.00 \pm 0.00$ \\
\hline
\end{tabular}

Values are averages of duplicate readings (mean $\pm S D$ ); $1 \mu \mathrm{g} \mathrm{RE}=6 \mu \mathrm{g}$ $\beta$-carotene

The moisture content of the mashed OFSP is about $72 \%$. It depends on the variety of OFSP and also on the amount of water which was present in the plastic in which the OFSP was tightened for the retention of $\beta$-carotene. The finding is in line with the report of $[25,34]$ on which the moisture content of 12 varieties of raw and boiled OFSP observed value $(69.5-83.9) \%$. The moisture content of the boiled OFSP was greater than that of raw, among the same varieties. Water added during cooking/boiling increases the moisture content of the product. This also strengthens the findings of the current study in such a way that varietal differences and being raw or boiled/cooked affects the moisture content of OFSP. The moisture content of mashed haricot bean is about 59\% (table1). Water was used for cooking the haricot bean and allowed it to be drained into the haricot bean to retain the minerals. This might be the reason to the moisture content to be higher. The moisture content of beans can also be varied due to 
varietal differences, production season and preparation methods.

As indicated in table 1, the protein content of mashed OFSP in dry basis is $4.59 \%$. The result is in line with the protein content value $(4.6 \%)$ of OFSP flour reported by [35], and similarly the protein content of pre-treated and dried OFSP flours with different methods observed value (4.1 - 5.76) $\%$ and $4.62 \%$. by [36] and [37], respectively. Whereas, the protein content of boiled and cooked haricot bean observed value were 23.6 and $18.4 \%$, respectively reported as [27]. Similarly, The protein contents of eight varieties of dry beans (Phaseolus vulgaris L.) grown in Ethiopian obtained value $(17.96-22.07) \%$ reported by [38]. This shows that the protein content varies with preparation methods and varieties.

The $\beta$-carotene content of the mashed OFSP is $4799 \mu \mathrm{g}$, which is equivalent to799 $\mu \mathrm{g} \mathrm{RE}$ (table 1). The studied OFSP flour $\beta$-carotene content observed value is within the reported variable amount of $\beta$-carotene content in nine cultivars ranged from $4760-13,845 \mu \mathrm{g} / 100 \mathrm{~g}$ by Reference [39]. However, the present studied result is lower than that reported by Reference [40], whose $\beta$-carotene content of boiled and mashed OFSP value was $3408 \mu \mathrm{g} / 100 \mathrm{~g}$. This shows the $\beta$-carotene content varies among the different genotypes. Reference [14] stated that the amount of total $\beta$-carotene in OFSP was higher even though there is loss during boiling, storage and drying. This indicates that boiled and mashed OFSP has potential to be a source of VA without to much losing of the nutrient VA. Since the aim of this study is formulating vitamin A and protein rich food, it is important to consider the protein contents of both mashed foods, OFSP and haricot bean. Beans are cheap protein sources to the poor. The current study revealed that the protein content of the mashed haricot bean is $19 \%$ and that of OFSP is about $5 \%$. Blending the two at different proportions provides a meal which contains greater protein than OFSP alone. Therefore, pre-school children get greater amount of protein if they consume a meal prepared from both OFSP and haricot bean. The other important micronutrient that needed to be given focus is vitamin A. OFSP is an excellent source of $\beta$-carotene but haricot bean is devoid of it. So, in a meal prepared from OFSP and haricot bean, one supplements VA and the other protein. As a result, VA deficiency and protein-energy malnutrition problem can be alleviated.

As it is indicated in table 1 the calcium, zinc and iron contents of mashed OFSP are 39.10, 0.40 and 0.74 $\mathrm{mg} / 100 \mathrm{~g}$, respectively. The result is in line with the calcium, zinc and iron contents of 12 varieties of boiled OFSP observed value $36-52,0.09-0.46$ and $0.28-2.49$ $\mathrm{mg} / 100 \mathrm{~g}$, respectively reported by [25]. Whereas, the haricot beans minerals (calcium, zinc and iron) contents obtained values were $58.93,3.5$ and $11.78 \mathrm{mg} / 100 \mathrm{~g}$, respectively. These observed values were somehow agreed with the cooked red kidney bean calcium (56.3), zinc (3) and iron (10.5) $\mathrm{mg} / 100 \mathrm{~g}$ contents reported Reference [27].

The tannin and phytate contents of mashed haricot bean, as shown in table 3 , are 803.74 and $104.35 \mathrm{mg} / 100 \mathrm{~g}$, respectively. Reference [41] reported the tannin and phytate contents of boiled haricot bean 864.33 and 122.72 $\mathrm{mg} / 100 \mathrm{~g}$, which is higher than the current study's result. This might be due to the differences in preparation methods, grown conditions and cultivars.

\section{Nutrient Composition of Foods Formulated from OFSP and Haricot Bean}

Nutrient contents of foods formulated from mashed OFSP and haricot bean are given in Table 2.The daily requirements for a $1-3$ and $4-6$ years old children are also given to help interpreting the nutrient values per $100 \mathrm{~g}$ of mashed foods.

Table 2. Proximate composition (\%) and $\beta$-carotene content of formulated foods per $100 \mathrm{~g}$ in comparison to preschool children's daily requirement.

\begin{tabular}{|c|c|c|c|c|c|c|}
\hline & \multicolumn{2}{|c|}{ Preschool children requirements } & \multicolumn{4}{|c|}{ Formulations (OFSP: haricot bean) } \\
\hline Composition & $\mathbf{1 - 3}$ yrs & $\mathbf{4 - 6 ~ y r s ~}$ & $\mathbf{1 0 0 : 0 0}$ & $\mathbf{9 0 : 1 0}$ & $\mathbf{8 0 : 2 0}$ & $\mathbf{7 0 : 3 0}$ \\
\hline Moisture & - & - & $72.10 \pm 0.67^{\mathrm{a}}$ & $69.71 \pm 0.62^{\mathrm{b}}$ & $68.47 \pm 0.31^{\mathrm{bc}}$ & $66.86 \pm 0.46^{\mathrm{c}}$ \\
Crude protein & 13 & 19 & $4.59 \pm 0.19^{\mathrm{d}}$ & $6.16 \pm 0.17^{\mathrm{c}}$ & $8.56 \pm 0.0 .59^{\mathrm{b}}$ & $10.52 \pm 0.32^{\mathrm{a}}$ \\
Crude fat & $19^{*}$ & $25^{*}$ & $1.62 \pm 0.05^{\mathrm{c}}$ & $1.82 \pm 0.08^{\mathrm{c}}$ & $2.25 \pm 0.13^{\mathrm{b}}$ & $2.92 \pm 0.08^{\mathrm{a}}$ \\
Ash & - & - & $1.39 \pm 0.18^{\mathrm{c}}$ & $1.76 \pm 0.06^{\mathrm{b}}$ & $1.92 \pm 0.02^{\mathrm{ab}}$ & $2.18 \pm 0.04^{\mathrm{a}}$ \\
Crude fiber & 19 & 25 & $2.23 \pm 0.28^{\mathrm{d}}$ & $2.81 \pm 0.06^{\mathrm{c}}$ & $3.07 \pm 0.08^{\mathrm{b}}$ & $3.49 \pm 0.04^{\mathrm{a}}$ \\
Carbohydrate & 130 & 130 & $20.29 \pm 0.62^{\mathrm{a}}$ & $20.06 \pm 0.43^{\mathrm{a}}$ & $18.80 \pm 0.13^{\mathrm{a}}$ & $17.53 \pm 0.25^{\mathrm{b}}$ \\
Energy (Kcal) & $992-1046$ & $1642-1742$ & $114.10 \pm 3.67^{\mathrm{d}}$ & $123.20 \pm 3.10^{\mathrm{c}}$ & $129.71 \pm 0.69^{\mathrm{b}}$ & $138.42 \pm 1.59^{\mathrm{a}}$ \\
$\beta$-carotene $(\mu \mathrm{g})$ & - & - & $4790.00 \pm 42.43 .0^{\mathrm{a}}$ & $4106.52 \pm 7.07 .0^{\mathrm{b}}$ & $3704.28 \pm 3.54 .0^{\mathrm{c}}$ & $3259.56 \pm 14.14^{\mathrm{d}}$ \\
V A $(\mu \mathrm{g}$ RE) & 400 & 450 & 799.93 & 684.42 & 617.38 & 543.26 \\
\hline
\end{tabular}

Values are averages of duplicate readings (mean \pm standard deviation). Means followed by different superscripts within the row indicate significant difference $(\mathrm{p}<0.05)(\mathrm{a}>\mathrm{b}>\mathrm{c}>\mathrm{d}) ; 1 \mu \mathrm{g} \beta$-carotene $=0.167 \mu \mathrm{g}$ RE (FAO and WHO, 2002). * Values are in Adequate Intake (AI). OFSP: orange flesh sweet potato, VA: vitamin A. 
As mashed haricot bean proportion increased, crude protein and crude fiber contents of the formulated foods increased significantly $(p<0.05)$. As the proportion of haricot bean increased the crude fat, ash and energy content of the formulated foods increased. In contrast, the moisture, carbohydrate and vitamin A content decreased. The significant difference of the protein content in the formulated foods might be due to high protein content of haricot bean, which is about four times that of OFSP (19.16 and 4.59$) \%$, respectively.

Expectedly, the significant difference in fiber contents of the formulated foods might be due to high fiber content of haricot bean. This might be due to the haricot bean was mashed together with the hull which is believed to contain high fiber. Consequently, the ash content of the formulated foods is increased as the proportion of haricot bean increased, this is due to the minerals content of haricot bean is higher than that of OFSP. When compared to the daily requirements of preschool children, the formulated foods can contribute to different extents. For example, $4-6$ year old children who consume $100 \mathrm{~g}$ mashed food formulated from 70:30 (OFSP: haricot bean) can get about $55 \%$ of the protein, $121 \%$ of Vitamin A, $8 \%$ of energy, $12 \%$ of fat, $14 \%$ of fiber and $13 \%$ of carbohydrate required for a day. Similarly, $1-3$ year old children who consume $100 \mathrm{~g}$ of 70 : 30 mashed foods can get $81 \%$ of protein, $136 \%$ of vitamin A, $13 \%$ of energy, $15 \%$ of fat, $18 \%$ of fiber and $13 \%$ of carbohydrate required for a day. By increasing the frequency of consumption (portion size), it is possible to increase the nutrients level in the formulated foods. But, the preschool children are not expected to eat only meal which is prepared from OFSP and haricot bean in a day. From this study survey, it was observed that they were consuming other foods rich in nutrients, like egg, milk and green vegetables, even though seldom. Therefore, the formulated food can complement the gap of the nutrients to improve the nutritional status of the preschool children. This can be one of the food based strategies to combat the protein and vitamin A deficiency from locally available crops.

\section{Minerals and Anti-nutrient Contents of the Formulated Foods}

The minerals' and anti-nutritional factors' content increased as the proportion of haricot bean increased (Table 3). This shows that haricot bean contains high amount of minerals and anti-nutritional factors when compared to OFSP. In addition, no pretreatment was applied on the haricot bean prior to cooking. Moreover, the remained water from cooking was allowed to be drained into the haricot bean. These all might have had contributed to the increment of the contents.

\section{Molar Ratio of Phytate to Minerals (Bioavailability) of the Formulated Foods}

The molar ratio between phytate and minerals was obtained after dividing the mole of phytate with the mole of minerals. The molar ratios are below the critical limits.

Table 3. Minerals' and anti-nutritional factors' content of the formulated foods

\begin{tabular}{|c|c|c|c|c|}
\hline \multicolumn{5}{|c|}{ Formulations (OFSP: haricot bean) } \\
\hline Nutrients & $\mathbf{1 0 0 : 0 0}$ & $\mathbf{9 0 : 1 0}$ & $\mathbf{8 0 : 2 0}$ & $\mathbf{7 0 : 3 0}$ \\
\hline Calcium $(\mathrm{mg} / 100 \mathrm{~g})$ & $39.10 \pm 3.20^{\mathrm{a}}$ & $40.41 \pm 0.78^{\mathrm{a}}$ & $41.07 \pm 0.08^{\mathrm{a}}$ & $42.73 \pm 0.78^{\mathrm{a}}$ \\
\hline Iron $(\mathrm{mg} / 100 \mathrm{~g})$ & $0.74 \pm 0.12^{\mathrm{c}}$ & $1.38 \pm 0.13^{\mathrm{bc}}$ & $2.74 \pm 0.14^{\mathrm{b}}$ & $4.31 \pm 0.23^{\mathrm{a}}$ \\
\hline Zinc $(\mathrm{mg} / 100 \mathrm{~g})$ & $0.40 \pm 0.23^{\mathrm{c}}$ & $0.89 \pm 0.04^{\mathrm{b}}$ & $1.32 \pm 0.08^{\mathrm{ab}}$ & $1.58 \pm 0.05^{\mathrm{a}}$ \\
\hline Phytate $(\mathrm{mg} / 100 \mathrm{~g})$ & $40.00 \pm 3.28^{\mathrm{c}}$ & $45.12 \pm 3.20^{\mathrm{bc}}$ & $51.15 \pm 3.14^{\mathrm{b}}$ & $58.74 \pm 1.97^{\mathrm{a}}$ \\
\hline Tannin $(\mathrm{mg} / 100 \mathrm{~g})$ & $56.14 \pm 3.14^{\mathrm{d}}$ & $95.88 \pm 2.34^{\mathrm{c}}$ & $157.38 \pm 5.71^{\mathrm{b}}$ & $211.44 \pm 2.99^{\mathrm{a}}$ \\
\hline
\end{tabular}

Values are averages of duplicate readings (mean \pm standard deviation). Means followed by different superscripts within the row indicate significant difference $(\mathrm{p}<0.05)(\mathrm{a}>\mathrm{b}>\mathrm{c}>\mathrm{d})$. OFSP: orange flesh sweet potato.

Table 4. Molar ratios of phytate to minerals and their critical limits

\begin{tabular}{|c|c|c|c|c|c|}
\hline \multicolumn{7}{|c|}{ Formulations (OFSP: haricot bean) } \\
\hline Molar ratios & $\mathbf{1 0 0 : 0 0}$ & $\mathbf{9 0 : 1 0}$ & $\mathbf{8 0 : 2 0}$ & $\mathbf{7 0 : 3 0}$ & Critical limits \\
\hline PA:Ca & 0.03 & 0.05 & 0.06 & 0.08 & $>1.56$ \\
\hline PA:Fe & 6.00 & 3.5 & 1.60 & 1.13 & $>14$ \\
\hline PA:Zn & 8.25 & 7.05 & 5.76 & 4.50 & $>10$ \\
\hline
\end{tabular}

PA: phytate, Ca: Calcium, Fe: Iron, Zn: Zinc, OFSP: Orange fleshed sweet potato. 
Table 4 shows the molar ratios of phytate to the three minerals are below the critical limits. Even though the molar ratios are below the critical limits, they are in the range to inhibit the bioavailability of the minerals. For example, Phytate/iron molar ratio $>1$ is an indication of poor iron bioavailability $[41,42]$. Ideally molar ratio of phytate to iron should be decreased to $<0.4$ to attain adequate iron bioavailability [43]. The reason behind the elevated molar ratios might be due to the preparation methods of the foods. The water remained after cooking of both OFSP and haricot bean was not discarded to retain $\beta$-carotene and minerals, respectively. Even though it helped retaining the mentioned nutrients, anti-nutritional factors might also retain together with. Anti-nutritional factors are expected to be concentrated on the hull of legumes [44]. The haricot bean was not dehulled so that this might also contributed to the increment of the availability of minerals.

\section{Conclusions}

Preschool children of the studied area were not consuming protein and vitamin A rich foods frequently to meet the recommended daily allowances. The proximate composition, energy, vitamin A and minerals contents of the formulated foods are promising to complement the RDA of preschool children if the formulated foods are included in daily dishes. The food formulated from $70 \%$ OFSP and 30\% haricot bean provides the highest crude (protein, fat and fiber), energy and minerals $(\mathrm{Ca}, \mathrm{Zn}, \mathrm{Fe})$ for RDA. As the haricot bean proportion increased in the formulated foods, minerals content, anti-nutrients content, bioavailability of zinc and iron increased but bioavailability of calcium decreased. The bioavailability was estimated in vitro, it has to be done in vivo.

\section{Acknowledgements}

We are grateful to CIP-Irish Aid project for their financial support, Dale woreda administration and agriculture office staffs. We are also thankful the studied area households who participated in the survey for their kind cooperation.

\section{REFERENCES}

[1] Müller O. and Krawinkel M. 2005. Malnutrition and health in developing countries. CMAJ, 173: 279-286.

[2] Broughton WJ, Hernandeze G, Blair M, Beebe S, Gepts P and Vanderleyden J. 2003. Beans are model food legumes.
Journal of Plant and Soil, 225: 55-128.

[3] Dilis V and Trichopoulou A. 2009. Nutritional and health properties of pulses. Mediterranean Journal of Nutrition Metabolism, 1: 149-157.

[4] Plat J, and Mensink RP.2005. Plant stanol and sterol esters in the control of blood cholesterol levels: mechanism and safety aspects. American Journal of Cardinals, 96 (1A): $15 \mathrm{D}-22 \mathrm{D}$.

[5] Kushwah A, Rajawat P and Kushwah HS. 2002. Nutritional evaluation of extruded Faba bean (Vicia fava) as protein supplement in cereal based diet in rats. Journal of Experimental Biology, 40 (1): 49 - 52.

[6] Yewulsew A., Barbara J. S., Margaret J. H., Gail E. G. 2006. Nutritive value and sensory acceptability of corn- and kocho-based foods supplemented with legumes for infant feeding in Southern Ethiopia; African Journal of Food, Agriculture, Nutrition and Development, 6 (1): 1-7.

[7] Abebe Haile, Martha Geribo and Esayas Kinfe. 2016. Evaluation of Porridge Made from Composite Flour of Orange-fleshed Sweet Potato and Enset (Bulla) Flours. Agriculture and Food Sciences Research, 3(1): 37-44.

[8] Burri B.J. 2011. Evaluating Sweet potato as an intervention food to prevent vitamin A deficiency. Comprehensive Reviews in Food Science and Food Safety, 10: 118 - 130.

[9] Institute of Medicine. 2000. Dietary Reference Intakes for Vitamin C, Vitamin E, Selenium and Carotenoids. Washington, DC: National Academy Press.

[10] Wilson P.W. and Ameny M.A. 1997. Relationship between Hunter color values and carotene contents in white-fleshed African sweet potatoes (Ipomea batatus). Journal of the Science of Food and Agriculture, 73:301-306.

[11] Christina S. 2007. Nutrient and sensory quality of Orange-fleshed sweet potato, School of Agriculture and Food Science, MSc. Thesis. University of Pretoria, South Africa. 98pp.

[12] Bekele Mekuria and Shimelis Admassu. 2011. Grain quality evaluation and characterization of gluten powder from bread wheat varieties grown in Arsi and Bale, Ethiopia. East African Journal of Science, 5 (2): 109-115.

[13] Moorthy S.N. 2002 Physicochemical and functional properties of tropical tuber starches: A review, Starch-Starke, 54 (12): $559-592$.

[14] Abebe Haile,Temesgen Lalego and Tigist Fikadu. 2015. Nutritional and Sensory Analysis of Cookies Enriched with $\beta$-carotene by Blending Orange-fleshed Sweet Potato (Ipomoea batatas L.) and Wheat (Triticum aestivum L.). International Journal of Food Science and Nutrition Engineering, 5(5): 209-217. DOI: 10.5923/ j.food.20150505.05).

[15] Van Jaarsveld P.J., Faber M., Tanumihardjo S.A., Nestel P., Lombard C.J., and Spinnler Benadé A.J. 2005. $\beta$-carotene rich orange-fleshed sweet potato improves the vitamin $\mathrm{A}$ status of primary school children assessed with the modified-relative-dose response. American Journal of Clinical Nutrition, 81:1080-1087. 
[16] Mitra S. 2012. Nutritional Status of Orange-Fleshed Sweet Potatoes in Alleviating Vitamin A Malnutrition through a Food-Based Approach. Journal of Nutrition and Food Science, 2:160. doi:10.4172/2155-9600.1000160

[17] Jalal F., Nesheim M.C., Agus Z., Sanjur D. and Habchit J.P. 1998. Serum retinol concentrations in children are affected by food source of $\beta$ - carotene, fat intake and anthelminthic drug treatment. American Journal of Clinical Nutrition, 68: $623-629$.

[18] Abadi Gebre, Tariku Zana and Abebe Haile. 2014. Development of Orange-Fleshed Sweet Potato (Ipomoea batatas) Juice: Analysis of Physico-Chemical, Nutritional and Sensory Property. (online at http://journal.sapub.org/food Copyright (C) 2014 Scientific \& Academic Publishing).

[19] Ndolo, P. J. Nungo, R. A. Kapinga, R. E. and Agili S. 2007. Development and promotion of orange-fleshed sweet potato varieties in Western Kenya, Proceedings of the 13th ISTRC Symposium Kenya Agricultural Research Institute-RRC-Kakamega, Kenya Nairobi, Arusha, Tanzania, pp. 689-690.

[20] Assefa Tofu, Teshome Anshebo, Engida Tsegaye and Tesfaye Tadesse. 2007. Summary of progress on orange fleshed sweet potato research and development in Ethiopia. Proceedings of the $13^{\text {th }}$ ISTRC Symposium, Ethiopia. pp 728 $-773$.

[21] Black, R. E., Victora, C. G. Walker, S. P. Bhutta, Z. A. Christian, p., de Onis M., Ezzati, M., Grantham-McGregor S., Katz, J. Martorell, R. and Uauy R. 2013. "Maternal and Child Undernutrition and Overweight in Low-Income and Middle-Income Countries.” Lancet 382 (9890): 427-451.

[22] Faber M., Laurie S. and Van Jaarsveld P. 2008. Nutrient content and consumer acceptability for different cultivars of orange-fleshed sweet potato. South African Sugar Association Project no 202.40pp.

[23] Fottrell E., Enquselassie F. and Byass P. 2009. The distribution and effect of child mortality risk factors in Ethiopia: a comparison of estimates from DSS and DHS. Ethiopian Journal of Health Development, 23: 163-168.

[24] Central Statistical Authority (CSA). 2012. Ethiopian Demographic Health Survey (EDHS) 2011. Addis Ababa, Ethiopia.

[25] Melkie Edris. 2007. Assessment of nutritional status of preschool children of Gumbrit, North West Ethiopia. Ethiopian Journal of Health Development, 21 (2):125-129.

[26] Kebebu A, Whiting SJ, Dahl WJ, CJ Henry and Kebede Abegaz. 2013. Formulation of a complementary food fortified with broad beans (vicia faba) in Southern Ethiopia. African Journal of Food, Agriculture, Nutrition and Development, 13 (2): ISSN 16845374.

[27] Audu S.S. and Aremu M.O. 2011. Effect of Processing on Chemical Composition of Red Kidney Bean (Phaseolus vulgaris L.) Flour. Pakistan Journal of Nutrition, 10 (11): 1069-1075.

[28] Owori C., Berga L., Mwanga R.O., Namutebi A. and Kapinga R. 2007. Sweet potato recipe book: Sweet potato processed products from Eastern and Central Africa, Kampala, Uganda, 93 p.
[29] AOAC (Association of Official Analytical Chemists). 2005. Official methods of Analysis of AOAC International, 17th edition, Vol. II. Washington, DC, USA.

[30] Rodriguez-Amaya, D.B., Rodriguez A. and Mieko K. 1988. Assesment of provitamin A determination by open Column Chromatography/ Visible Absorption Spectrophotometery. Journal Chromatographic Science, 26: 624-29.

[31] Latta, M. and Eskin, M. (1980). A simple and rapid colorimetric determination of phytate determination, Journal of Agricultural Food Chemistry, 28: 1313-1315.

[32] Maxon, E.D. and Rooney, L.W. (1972). Evaluation of method for tannin analysis in sorghum grain. Cereal chemistry, 49:719-729.

[33] Morris E.R. and Ellis R. 1980. Bioavailability to rats of iron and zinc in wheat bran: response to low-phytate bran and effect of the phytate/zinc molar ratio. Journal of Nutrition, 110.

[34] Abebe Haile, Martha Geribo and Esayas Kinfe. 2015. The Effects of Blending Orange-Fleshed Sweet Potato with Enset (Enset ventricosum) Kocho on $\beta$-Carotene Content of Flat-Bread. Journal of Nutritional Ecology and Food Research, Vol. 3: 62-68.

[35] Low J.W., Arimond M., Osman N., Cunguara B., Zano F. and Tschirley D. 2007. A Food-Based Approach Introducing Orange-Fleshed Sweet Potatoes Increased Vitamin A Intake and Serum Retinol Concentrations in Young Children in Rural Mozambique. The Journal of Nutrition, 137:1320 1327.

[36] Fana Haile, Shimelis Admassu and Abrehet Fisseha. 2015. Effects of Pre-treatments and Drying Methods on Chemical Composition, Microbial and Sensory Quality of Orange-Fleshed Sweet Potato Flour and Porridge. American Journal of Food Science and Technology, (3) 3: 82-88.

[37] Gebremedihin Kidane, Kebede Abegaz, Afework Mulugeta and Pragya Singh. 2013. Nutritional analysis of vitamin A enriched bread from orange flesh sweet potato and locally available wheat flours at Samre woreda, Northern Ethiopia. Journal of Current Research in Nutrition and Food Science, $1(1), 49-57$.

[38] Shimelis Admassu and Rakshit S.K. 2005. Proximate composition and physico-chemical properties of improved dry bean (Phaseolus vulgaris L.) varieties grown in Ethiopia. Journal of Lebensmittel-Wissenschaft Und-Tebchnologie, 38: $331-338$.

[39] Mieke Faber, Sunette Laurie and Paul van Jaarsveld. 2008. Nutrient content and consumer acceptability for different cultivars of orange-fleshed sweet potato: South African Sugar Association Project no 202.

[40] Hagenimana V., Low J., Anyango M., Kurz K., Gichuki S.T. and Kabira J. 2001. Enhancing Vitamin A intake in young children in Western Kenya: Orange-fleshed sweet potato and women farmers can serve as key entry points. Food and Nutrition Bulletin, 22: 276 - 387.

[41] Tamanna S., Parvin S, Kumar S., Alak K, Dutta A. Ferdoushi M, Siddiquee A., Sunil B., Zakir M and Howlader H. 2013. Content of some minerals and their bioavailability in selected popular rice varieties from Bangladesh. International Journal of Current Microbiology, 2 (7): 35-43. 
[42] Abebe Haile, Negussie Retta and Cherinet Auye, 2016. Evaluation of common is processing methods on selected minerals, anti-nutritional factor and its bioavailability of seven cultivars of cassava roots (Manihot esculenta C.) grown in Ethiopia. CCDN News, No 27, 5-10.

[43] Hurrell RF. 2003. Influence of Vegetable Protein Sources on Trace Element and Mineral Bioavailability. Journal of Nutrition, 133: 2973S-2977S.

[44] Mubarek A.E. 2005. Nutritional composition and antinutritional factors of mung bean (Phaseolus aureus) as affected by some home traditional processes. Journal of Food Chemistry, 89: 489 - 495. 